\title{
STRATEGI MEDAN INVESTMENT, TRADE \& TOURISM EXPO DALAM MENJALANKAN DIPLOMASI PARIWISATA SUMATERA UTARA DENGAN MALAYSIA
}

\author{
Nirwaty Tarigan \\ Akademi Pariwisata dan Perhotelan Darma Agung
}

\begin{abstract}
Tourism has strategic economic value for the country, not onlyit generate income for the country but also improve the economic life of the surrounding population. With this, the Government of the Republic of Indonesia advised local governments to promote the tourism out of the country to introduce the tourism potential of the region and national as well as in the public diplomacy.According to that,Medan Investment, Trade \& Tourism Expo (MITT) has established offices in different countries, one of which is in Malaysia. This study analyzed the role ofMITT in Malaysia as a commitment to promote tourism in Sumatera Utara. The authors examined the amount of travelers to Sumatera Utara from Malaysia.
\end{abstract}

Keyword :Tourism, Expo, Sumatera Utara

\section{Pendahuluan}

Perubahan lingkungan strategis baik di tingkat global maupun regional sangat mempengaruhi penekanan kebijakan luar negeri Indonesia. Perubahan lingkungan internasional tersebut tidak hanya disebabkan oleh dinamika hubungan antarnegara, tetapi juga oleh perubahan isu, dan fenomena munculnya aktor-aktor baru dalam hubungan internasional, khususnya non-state actors. Untuk hal tersebut politik luar negeri Indonesia perlu didesain untuk mampu mempertemukan kepentingan nasional Indonesia dengan Iingkungan internasional yang selalu berubah. Tidak dapat dipungkiri perlunya politik luar negeri yang luwes dan flexible untuk menghadapi segala tantangan dimaksud.

Di awal proses perkembangan disiplin ilmu hubungan internasional telah diasumsikan bahwa disiplin ini merupakan segala sesuatu yang berkaitan dengan cakupan semua relasi antar negara, seperti yang dilansir oleh Schawarzenberger yang menyatakan bahwa disiplin ilmu hubungan internasional adalah bagian dari ilmu sosiologi yang khusus mempelajari masyarakat internasional (sociology of international relation $)^{1}$.Dalam artian bahwa ilmu hubungan internasional tidak hanya mencakup unsur yang berkaitan dengan politik saja tetapi lebih luas lagi seperti bidang ekonomi, sosial budaya, pertahanan keamanan atau bahkan pada sektor pariwisata misalnya kegiatan pertukaran budaya (cultural exchange). Otonomi daerah diera globalisasi saat ini, sangat berpengaruh pada strategi pemda dalam memanfaatkan sumber daya alam daerahnya. Akibatnya, pemda memungkinkan melakukan kerjasama bahkan hubungan luar negeri dengan negara lain. Artinya, hubungan kerjasama tersebut didasari saling membutukan dan saling menguntungkan antara kedua belah

\footnotetext{
${ }^{1}$ Banyu Perwita Anak Agung \&Yanyan Mochamad Yani. Pengantar Ilmu Hubungan Internasional. PT. Remaja Rosdakarya, Bandung, 2006 Hal.2
} 
pihak baik itu aktor negara atau yang diwakili oleh Penmerintah Daerah atau aktor lainya yang bekerjasama dengan investor asing. Oleh sebab itu, untuk menjamin hubungan kerjasama yang baik antara kedua belah pihak maka diperlukan cara sebagai sebuah proses dalam memperjuangkan berbagai kepentingan masing-masing pihak yang bekerjasama. Sebuah cara komunikasi yang efektif merupakan salah satu pendukung dalam hubungan kerjasama tersebut, yang dalam disiplin ilmu hubungan internasional sering disebut dengan diplomasi. Dimana maksud dari diplomasi adalah suatu cara komunikasi dengan pemilihan kata serta kalimat yang dilakukan berbagai pihakpihak termasuk negosiasi antara wakilwakil yang diakui untuk meraih kepentingan kita sendiri. ${ }^{2}$

Pariwisata merupakan komoditi yang perlu dikembangkan karena dapat menjadi salah satu alat untuk mendorong pertumbuhan ekonomi dan berpengaruh signifikan terhadap perekonomian masyarakat. Beberapa negara bahkan mengandalkan industri pariwisata sebagai pendapatan utama. Hal ini mendorong setiap negara berlomba-lomba menciptakan dan menawarkan berbagai macam destinasi untuk menikmati berbagai produk wisata dan fasilitas yang tersedia.

Disinilah muncul kebutuhan adanya sebuah lembaga/unit yang mampu berperan sebagai pelaksana pengembangan pemasaran dan promosi dalam konteks industri pariwisata secara keseluruhan, yang tugasnya mengembangkan program/kegiatan pemasaran dan promosi

2 Zainal Abidin Partao. Teknik Lobi dan Diplomasi : Untuk Insan Public Relations, Jakarta: PT. Indeks .2007. hal. 35 . secara profesional. Selama ini pandangan umum wisatawan mancanegara terhadap Indonesia hanya terpusat pada destinasi atau obyek wisata utama misalkan Jakarta, Bali, Lombok, dan Yogyakarta yang ditetapkan sebagai daerah tujuan wisatawan asing. Menghadapi fenomena ini Pemerintah Kota Medan telah melakukan langkah-langkah untuk memulihkan citra positif pariwisata Indonesia, diantaranya lewat diplomasi antar negara secara berkesinambungan maupun organisasi internasional yang bersifat regional di bidang pariwisata, salah satunya dengan mengusulkan pembentukan Medan Investment, Trade \& Tourism Expo (MITT).

Pembentukan MITT ini bertujuan untuk mempromosikan Sumatera Utara sebagai destinasi pariwisata. MITT fokus di aspek promosi dengan membuka akses promosi/pemasaran di target - target pasar melalui pembukaan 5 kantor representative di luar negeri: Eropa (Swedia), Korea, Philippine, Malaysia, China (Shenzhen) dan 3 kantor representative dalam negeri: Balikpapan, Jakarta, Yogyakarta. Institusi MITT terdiri dari unsur pelaku usaha, perwakilan asosiasi, perwakilan perguruan tinggi (universitas) dan Pemda (Disbudpar Kota Sumatera Utara). ${ }^{3}$

Penulis memilih Malaysia dalam penelitian ini dikarenakan Malaysia merupakan negara tertangga yang berdekatan dengan Indonesia, Sumatera Utara pada khususnya. Malaysia yang secara geografis juga merupakan kawasan Asia Tenggara merupakan negara yang

\footnotetext{
3 Adjie Wahjono, wawancara langsung, Sekjen MITT (Operations Manager Aneka Kartika Tours \& Travel), 26 Mei, 2012.
} 
makmur dengan pendapatan masyarakat yang besar di wilayah Asia Tenggara.

MITT menganggap Sumatera Utara sebagai jantung bisnis ketiga di Indonesia setelah Jakarta dan Surabaya memang layak dikunjungi turis asing. ${ }^{4}$ Apalagi bukan hal yang sulit bagi masyarakat Malaysia untuk ke Sumatera Utara dikarenakan cukup banyaknya frekuensi penerbangan langsung dari Malaysia ke Sumatera Utara . ${ }^{5}$ Ditambah dengan kultur budaya yang tidak begitu memiliki banyak perbedaan, sehingga memudahkan masyarakat Malaysia yang akan berwisata. Alasan lain penulis memilih Malaysia sebagai penelitian adalah karakter masyarakatnya yang shopaholic.

\section{Hubungan Luar Negeri Dalam Kerangka Otonomi Daerah}

Upaya pengembangan pariwisata merupakan tugas seluruh stakeholders pariwisata di daerah (baik pemerintah, swasta, dunia pendidikan dan organisasi masyarakat terkait). Dalam konteks pengembangan infrastruktur, sarana dan prasarana, industri pariwisata telah memanfaatkan berbagai produk yang telah dibangun dan dikembangkan oleh pemerintah.

Sektor ini mampu mendatangkan banyak keuntungan dalam segi ekonomi dan sosial budaya sebabmampu menciptakan investasi, meningkatkan pendapatan masyarakat, kualitas hidup masyarakat, dan menanamkan rasa cinta tanah air sesuai instruksi Presiden RI No. 9 Tahun 1969tentang kepariwisataan ${ }^{6}$ yang

\footnotetext{
4"Sparkling Sumatera Utara Rambah Malaysia," Kompas, 28 Desember 2006.

5"MITT tawarkan ke Malaysia," Radar Sumatera Utara, 20 Desember 2006.

${ }^{6}$ Lampiran
}

tercantum dalamGaris-Garis Besar Haluan Negara (GBHN) dan Undang-Undang No.9 Tahun 1990 dan di revisi menjadi Undang-Undang No.10.Tahun 2009. ${ }^{7}$

Memaksimalkan kembali peran pemda dalam mengelola potensi daerah yang dimiliki dalam hubungan luar negeri dengan negara lain maka Pemerintah Republik Indonesia melegalkan bentuk pembuatan Undang-Undang tata cara hubungan laur negeri (Undang-undang No.37 Tahun 1999 ) dan Undang-undang perjanjian internasional ( Undang-undang No.24 Tahun 2000) untuk memberi batasan ruang gerak bagi pemda dalam melakukan hubungan luar negeri. Dengan lahirnya kedua Undang-undang ini menjadi dasar hukum sah bagi pemdauntuk melakukan hubungan luar negeri.

Menurut Undang-Undang No.37 Tahun 1999 tentang hubungan luar negeri, menjelaskan bahwa hubungan luar negeri di artikan sebagai setiap kegiatan yang menyangkut aspek regional dan internasional yang dilakukan oleh Pemerintah di tingkat pusat dan daerah, atau lembaga-lembaganya, lembaga negara, badan usaha, organisasi politik, organisasi masyarakat, lembaga swadaya masyarakat, atau warga negara Indonesia. Dimana, hubungan luar negeri tersebut merupakan usaha implementasi kebijakana luar negeri Indonesia yang dibentuk dalam berbagai strategi dan tindakan dalam menghadapi Negara lain atau aktor pilitik internasional lainya yang dilakukan oleh para pengambil keputusan di Indonesia

${ }^{7}$ Oka A. Yoeti .Pengantar Ilmu Pariwisata : Bandung, Penerbit Aksara Bandung. 1987. hal.138. 
dalam usaha pencapaian kepentingan nasional. ${ }^{8}$

Selain itu, Undang- undang ini juga mengatur aktor yang bisa melakukan hubungan luar negeri yakni: Departemen Luar Negeri RI, Mentri Dalam Negeri, Kementrian Teknis, Lembaga non Pemerintah Diplomat atau Perwakilan RI serta pemda. Pemda merupakan penyelengara urusan pemerintahan pada tingkat provinsi, kabupaten dan kota yang bertugas membantu dengan prinsip otonomi yang seluas-luasnya bagi Kesatuan Republik Indonesia. ${ }^{9}$

Hubungan luar negeri harus tetap merupakan masalah yang sangat penting. Hal ini, didasarkan pada tidak ada satu pun negara di dunia ini dapat melepaskan dirinya dari hubungan dengan negara lain. Sehingga, dapat menciptakan saling ketergantungan satu sama lain, apalagi dalam gelombang globalisasi sekarang ini justru setiap negara harus makin meningkatkan kelihaiannya dalam berinteraksi dengan negara lain dan lembaga- lembaga internasional. Apalagi dalam konteks otonomi daerah yang jelas mememiliki peluang untuk kerjasama luar negeri tersebut. Oleh karena, dengan bantuan kerjasama asing tidak menutup kemungkinan dapat memaksimalkan peran Pemerintah Daerah mampu memajukan ekonomi daerahnya.

Akan tetapi, hubungan luar negeri itu sendiri yang diterapkan oleh Indonesia memang memiliki peluang yang sangat besar untuk memajukan ekonomi nasional dengan memaksimalkan peran daerah. Namun demikian, prinsip hubungan luar negeri tetap mengacu pada kebijakan one

\footnotetext{
${ }^{8}$ Widjaja, h1.5

${ }^{9}$ Widjaja, h16.
}

doorpolicy ,yang merupakan sebuah realitas nasional yang seharusnya disikapi dengan baik oleh Pemerintah daerah. Dimana, realitas tersebut merupakan peluang dan tantangan yang menjanjikan dengan memberi kesempatan kepada setiap Pemerintah Daerah untuk lebih kreatif dalam mengambil langkah dan kebijakan yang konstruktif, efektif, efisien, dan partisipatif dalam memaksimalkan pengembangan potensi daerah yang dimilikinya. ${ }^{10}$ Dengan demikian, setidaknya Pemerintah Daerah selalu sadar akan amanah yang di embannya untuk memajukan ekonomi rakyatnya demi terciptanya kesejateraan ekonomi nasional yang telah di cita-citakan dalam Undang undang Dasar 1945. Mekanisme pelaksanaan hubungan luar negeri dalam konteks otonomi daerah tetap tidak lepas dari kontrolPemerintah Pusat yakni Departemen Luar Negeri sebagai aktor utama dalam melakukan hubungan luar negeri dengan pihak atau Negara lain terutama para investor asing.

Oleh karena, Pemerintah RI yakni Departemen Luar Negeri menyiasati hal tersebut dengan menerbitkan panduan umum tata cara hubungan dan kerjasama luar negeri oleh pemda dimana Departemen Luar Negeri dengan pemda terjadi sinkronisasi antara kedua pihak. Sehingga, Departemen Luar Negeri sebagai aktor utama hubungan dan kerjasama luar negerimenjadi parrner utama dan koordinator dalam membantu

\footnotetext{
10 Armin Arsyad dan Aspiannor Masrie. Jurnal, Hubungan Luar Negeri Dalam Kerangka Otonomi Daerah ( Studi Kasus: Provinsi Sulawesi Selatan), Makassar: Jurusan Politik Pemerintahan, Fakultas IImu Sosial dan IImu Politik,Universitas Hasanudin, 2010.hal.4
} 
Pemerintah Daerah dalam melaakukan kerjasama dan hubungan luar negeri.

Pemerintah Kota Medan memiliki pelung yang begitu besar dengan diterbitkannya tiga Undang -undang yakni Undang undang Otonomi Daerah sebagai aturan yang mengatur wewenang pemda, dan Undang -undang Hubungan Laur Negeri serta Undang- undang Perjanjian Internasional yang melegalkan dan mensahkan dan memberi kesempatan kepada pemda untuk melakukan hubungan luar dengan pihak Negara lain. Oleh karena, pemda sebagai salah satu aktor hubungan luar negeri selalu berupaya berkoordinasi dan melakukan konsolidasi dengan koordinatornya dalam hal ini adalah Departemen Luar Negeri untuk mengajukan program- program kerja sebelum melakukan hubungan laur negeri dengan pihak asing. Jadi, dapat disimpulkan tuliskan bentuk mekanisme hubungan luar negeri yang bisa dilakukan oleh pemda yakni dalam bentuk gambar: ${ }^{11}$

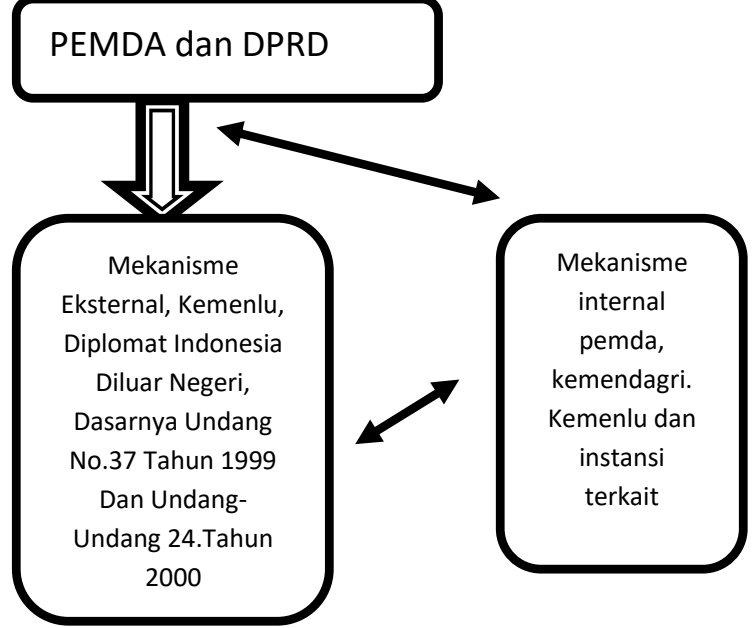

Gambar 1. Hubungan Luar Negeri Indonesia Dalam kerangka OTODA

${ }^{11}$ http;//

setda.bantulkab.go.id /documents/20110308095052-kerjasama-luarnegeri-oleh-pemerintah-daerah.pdf. di akses pada 15 Mei 2012
Dari gambar tersebut dapat dijelaskan bahwa pola hubungan luar negeri yang harus dijalankan oleh pemda sesuai tuntunan Undang- undang yakni Pemerintah Daearah harus saling berkoordinasi dengan DPRD setempat sebelum melakukan koordinasi dengan koordinator hubungan luar negeri yakni bebereapa instasnsi terkait yang di pimpin oleh Kementrian Luar negeri sebagai aktor utama hubungan luar negeri. Dalam artian bahwa mekanisme tersebut merupakan mekanisme yang harus dilalui oleh Pemerintah Daerah dalam internel negara sedangkan mekanisme eksternal langsung diwakili oleh diplomat Indonesia yang ada di luar negeri.

\section{Perkembangan MITT Serta Strategi Diplomasi Dengan Malaysia2019}

Seperti halnya sebuah perusahaan atau lembaga, MITT juga mengalami tumbuh dan berkembang. Dalam rangka mempromosikan kota Sumatera Utara sebagai kota tujuan wisata kepada khalayak internasional dan domestik, maka dibentuklah Tim Medan Investment, Trade \& Tourism Expo.

Dengan adanya perwakilan tiap kabupaten dan kota di Sumatera Utara diberbagai daerah maka MITT dapat lebih dekat dengan calon wisatawan sehingga kebutuhan mereka akan informasi mengenai kota Sumatera Utara dapat terpenuhi. Ditambah dengan langkah MITT untuk mengajak beberapa pengusaha tour and travel di tiap-tiap daerah/negara kantor perwakilan. ${ }^{12}$

12 "MITT Bentuk Perwakilan di Eopa", dalam Sumatera Utara Post minggu, 4 februari 2007. 
Promosi melalui media cetak merupakan kegiatan yang paling banyak dilakukan. Sejak terbentuk, MITT secara rutin membuat press release di Sumatera Utara dan di luar Sumatera Utara untuk selalu mempromosikan kegiatan-kegiatan yang dilakukan oleh pemerintah kota maupun swasta, khususnya yang mempunyai daya tarik bagi para wisatawan.Hampir semua media cetak pernah memuat berita tentang MITT. Salah satunya juga dengan dicetaknya Sumatera Utara City Guide. Setiap edisi disebarkan ke seluruh penjuru Medan dan wilayah Sumatera Utara, bahkan juga ke beberapa negara lain di antaranya ke Malaysia, Philipina dan Eropa. ${ }^{13}$. Penyebaran difokuskan pada hotel, bandara, taxi, serta Kantor perwakilan MITT diluar Negeri.Disamping itu MITT juga memasang iklan di Harian Nasional Kompas, Garuda inflight magazine, Sriwijaya flight magazine, dan Majalah Pariwisata. Kota kota di Indonesiapun tidak luput dari bidikan MITT dalampenyebaran press release, termasuk Balikpapan, Makasar, Jakarta, Semarang, Bali dan kota-kota lain di pulau Jawa dan Indonesia Timur. ${ }^{14}$

Melalui MITT, mencoba mempromosikan Sumatera Utara dengan tujuan agar siapapun bisa dengan mudah mencari informasi pariwisatanya. Disamping itu website yang dibuat oleh MITT sudah mulai dipakai sebagai sumber berita oleh beberapa media tentang kegiatan yang ada di Sumatera Utara.

13 Laporan Pertanggung Jawaban MITT Tahun 2006. H.4

${ }^{14}$ Adji Wahjono. Wawancara Pribadi
Dilain hal, MITT juga meggunakan cara familirization trip (fam trip) $)^{15}$ dalam mempromosikan Sumatera Utara pada wisatawan asing. Karena Fam Trip biasanya diikuti oleh media massa atau biro perjalanan yang banyak menulis dan menjual paket - paket wisata, maka mereka akan lebih mudah membuat paketpaket wisata ke Sumatera Utara. Media promo lainnya yang di gunakan adalah media radio dan televisi. Televisi merupakan media yang paling efektif karena visual, tetapi biaya yang dikeluarkan oleh MITT cukup banyak jika promosi melalui media televisi.

Sejak awal Medan Investment, Trade \& Tourism Expo (MITT) mulai melirik Malaysia sebagai pasar potensial. Hal itu berdasarkan dari kunjungan Familirazation Trip Group (pelaku tour and travel) Malaysia pada februari tahun 2006 yang menjajaki kerja sama wisata dengan MITT. ${ }^{16}$ Rombongan yang terdiri dari 6 biro perjalanan wisata dibeberapa kota di Malaysia tersebut mengunjungi beberapa obyek wisata baik yang ada di Sumatera Utara dan kota-kota lainnya.

Obyek wisata yang ada di Sumatera Utara bermacam-macam mulai dari wisata budaya, wisata olahraga, wisata rekreasi, wisata bahari, wisata bisnis, dan wisata religi. Di antara sekian banyak obyek wisata di Sumatera Utara, yang menjadi andalan dan selalu dikunjungi wisatawan adalah wisata alam Danau Toba, dan

\footnotetext{
15 Dalam http://www.travel-industrydictionary.com/familiarization-trip.html, diakses 2 oktober 2012

16 "Wisata Sumatera Utara Dilirik Malaysia Darussalam," Sumatera Utara Post, 21 februari, 2006 (edisi nasional).
} 
wisata religi. Apalagi calon wisatawan Malaysia yang mayoritas muslim.

Beberapa biro perjalanan dari Malaysia memberikan komitmen untuk menjual paket wisata Sumatera Utara karena mereka ingin mengembangkan destinasi baru yang belum banyak dikenal selain Bali. Sedangkan konsumen mereka tidak hanya orang Malaysia tetapi juga para expatriat yang ada di Malaysia. Pameran MITT mampu meingkatkan kerjasama antar biro perjalanan wisata, sampai berbagai media yang ada di Malaysia melalui familiarization trip untuk lebih meyakinkan masyarakat Malaysia agar dapat melihat secara langsung kondisi Sumatera Utara sehingga mereka lebih cepat merealisasikan komitmennya.

\section{Kesimpulan}

Berdasarkan pada hasil penelitian dan pembahasan pada bab sebelumnya maka pada bab ini penulis menarik kesimpulan dan saran bahwa selama rentan tahun 2019, MITT telah melakukan kegiatan yang cukup banyak memberikan dampak nyata pada masyarakat kota Sumatera Utara, wisatawan Malaysia dan industri pariwisata khususnya. MITT tidak menyerah dalam upayanya menjual Sumatera Utara. Untuk ukuran kota dengan industri wisata yang belum maju, MITT telah memiliki perwakilan di negara-negara lain. MITT juga gencar mengenalkan tagline Sumatera Utara sebagai 'Sparking Sumatera Utara' serta rajin membuat even-even wisata dan mengikuti promosi di Malaysia maupun negara lainnya.

Pamor Sumatera Utara sebagai salah satu kota pariwisata di Indonesia mulai terangkat. Hal ini terlihat dari maraknya kegiatan promosi kota Sumatera Utara yang sudah mulai menunjukan hasil. Ini juga akibat keseriusan para pelaku pariwisata maupun Pemkot Sumatera Utara menjadi tuan rumah berbagai kegiatan berskala nasional maupun internasional. Kemampuan MITT dalam menjalin hubungan dengan pihak-pihak yang terkait dengan kepariwisataan telah membuat MITT juga berhasil membantu Indonesia dalam memperbaiki kondisi kepariwisataan di Indonesia.

Pada tahun sebelumnyan, Biro Perjalanan Wisata di Sumatera Utara juga turut serta mempertahankan kelangsungan hidupnya juga untuk meningkatan wisatawan ntara Iain dengan menggalakkan penjualan paket wisata dengan discount yang menarik, membuat paket wisata inbound. Namun usaha-usaha tersebut tidak seluruhnya berhasil dengan baik. Banyak hambatan ,antara lain di sebabkan oleh kondisi politik negara yang saat ini masih tidak menentu sehingga banyak wisatawan mancanegara enggan datang ke Indonesia. Anggaran promosi seharusnya selalu ditingkatkan sesuai dengan peningkatan pendapatan daerah khususnya dari sektor pariwisata. Selama 3 tahun tersebut, kecukupan anggaran terjadi karena ditopang oleh para pelaku pariwisata yang memberikan fasilitas tanpa biaya. Jika pemerintah bisa jeli dalam membaca situasi, seharusnya anggaran harus ditingkatkan untuk lebih menarik wisatawan mancanegara. Karena waktu terus berjalan dan teknologi semakin canggih sehingga terjadi sebuah persaingan antar daerah.

Hal penting yang diharapkan dari pengembangan pariwisata daerah adalah 
semakin dikenalnya obyek wisata Sumatera Utara selain Danau Toba pada masyarakat luas yang akan berimplikasi terhadap peningkatan jumlah kunjungan wisatawan sehingga secara otomatis akan memberi kontribusi terhadap pendapatan daerah kabupaten dan kota di Sumatera Utara.

\section{Daftar Pustaka}

Holsty. Politik Intrnasional : Suatu Kerangka dan Analisis. Bandung: Bina Cipta, 1987.

Krisna, Didi. Kamus Politik Internasional. Jakarta: Grasindo, 1993.

Kusumohadimidjojo, Budiono. Hubungan Internasional: Kerangka Studi Analisis. Jakarta: Bina Cipta, 1987.

Linton, Ralph. 1936. The Study of Man (An Introduction). New York: Apleton Century-Crofts, Inc.

Nye, Joseph S. Jr. Soft Power the Means to Success in World Politics. NewYork: Public Affairs. 2004

Partao, Zainal Abidin. Teknik Lobi dan Diplomasi : Untuk Insan Public Relations. Jakarta: PT. Indeks, 2007.

Pendit, Nyoman S. Ilmu Pariwisata Sebuah Pengantar Perdana. Jakarta: PT.Pradnya Paramita, 2003.

Perwita, Banyu, Anak Agung \&Yanyan Mochamad Yani. Pengantar Ilmu Hubungan Internasional. Bandung: PT. Remaja Rosdakarya, 2006.

Silalahi, Ulber. Metode Penelitian Sosial. Bandung: PT Refika Aditama, 2009
Subagyo, Joko. Metode Penelitian: Dalam

Teori dan Praktek. Jakarta: Rajawali Press, 1997.

Suwantoro, Gamal. Dasar-dasar Pariwisata. Yogyakarta: cetakan II penerbit Andi, 2004.

Widjaja. Otonomi Daerah dan Daerah Otonom. Jakarta: PT.Raja Grafindo Persada, Rajawali Pers, 1997.

Yoeti, Oka A. Pengantar Ilmu Pariwisata. Bandung: Penerbit Aksara Bandung, 1997. 